\title{
THE DEVELOPMENT OF ORACY SKILLS IN AN EFL CONTEXT USING YOUTUBE VIDEOS: A CASE STUDY
}

\author{
Soumela Georgiadou ${ }^{1 *}$, and Makrina Zafiri ${ }^{2}$ \\ ${ }^{1}$ English Foreign Language Teacher, Hellenic Open University, Greece, \\ georgiadoumelina@gmail.com \\ ${ }^{2}$ Permanent at the Aristotle University of Thessaloniki,Academic Associate at the Hellenic Open \\ University, Teacher Trainer for the Greek National Teacher's Training Center (ASPAITE) in \\ Thessaloniki, Greece,m nzafiri@yahoo.gr \\ ${ }^{*}$ Corresponding Author
}

\begin{abstract}
The present study aims to examine the effectiveness of YouTube videos in the oracy skills of a young learner through the implementation of differentiated instruction. The research which was conducted was a case study and qualitative data were collected through the use of semi-structured interviews. Action research was also conducted through a series of ten YouTube-video based lessons grounded with the principles of differentiated instruction. The efficiency of the methods and approaches which were implemented were verified by the results of the pre- and post-listening and speaking test that was applied before and after the intervention of the ten lessons. To triangulate the study, qualitative research was conducted in the form of semi-structured interviews to the student and his mother before and after the intervention. The findings showed that there was an improvement in the student's performance as regards the listening, the speaking, and the grammar-lexis structure skills.
\end{abstract}

Keywords:YouTube, oracy skills, video, technology, case study.

\section{INTRODUCTION}

This research study endeavors to investigate the enhancement of oracy skills through the use of YouTube videos to a fifteen-year-old English language learner of B2 level with the application of differentiated instruction. In this realm, specific research questions are formulated:

1. Do YouTube-based video lessons enhance listening skills?

2. Do YouTube-based video lessons enhance speaking skills?

3. Can the student improve the sentence structure and formation through YouTube-based video lessons?

In order to answer to the aforementioned questions a case study is conducted. Case study methodology provides tools to the researcher to thoroughly examine complex phenomena within their contexts (Baxter \& Jack, 2015). Furthermore, this research is an action research as the researcher is also the teacher who decided to examine her own teaching situation. Namely, a series of ten differentiated YouTube-video based lessons are taught to the language student in order to refine his oracy skills. A performance listening and speaking skills test is implemented before and after the intervention so as to scrutinize upon the student's overall performance with regard to the aforementioned modalities. To triangulate the research so as to 
ensure its validity and reliability a qualitative research is also conducted through the use of semi-structured interviews to the boy and his mother. The researcher applied differentiated instruction as she anticipates that it will facilitate the process of learning and ameliorate student's oracy skills.

\section{THEORITICAL FRAMEWORK}

\subsection{The Oracy Skills in EFL}

Oracy is the ability to express ideas effectively, understand spoken language and respond appropriately. The term was coined in 1965 by Andrew Wilkinson in order to highlight the significance of speaking and listening skills which were "shamefully neglected" according to him until then, and acknowledge oracy as being of equal importance to literacy and numeracy (Wilkinson, 1965). He defined oracy as the ability to speak and understand spoken language (Wilkinson, 1962). Oracy is of major significance since it constitutes the basic form of communication among people which enables them to express themselves, their inner thoughts, feelings, opinions and ideas. Spoken language is a unique characteristic of the human species and a key to our evolution and civilization (Tomasello, 2010). People develop oral competence gradually and learn from interactions with other people (Kaldahl et al, 2019). Spoken communication is foundational to education, in general, and language learning, in particular. It is the dominant way in which teachers instruct and students learn and develop cognitively from teachers' or peers' responses (Alexander, 2012). Hughes (2002) claims that interaction amongst students or between teacher and students has an impact on language learning. Talk lies at the heart of language learning; it assists thinking and that means it assists learning. Vygotsky (1962) acknowledged the dynamic connection between language and thought. He recognized that speech is central to develop new ways of thinking and communication with a more skilled person, peer or adult, in the 'zone of proximal development', which is the gap between what learners can do on their own and what they can accomplish with guidance, constitutes interaction integral to learning (Jones, 2016). The term oracy underlines the strong and bidirectional relationship between the skills of speaking and listening. In more detail, oracy is a two-way process between interlocutors and as such, it involves the productive skill of speaking since a form of linguistic output is demanded, and the receptive skill of listening in which the input is received and understood (Kaldahl et al,2019). The inter-relatedness between the aforementioned skills is complex and one skill supports the development of the other (Kaldahl et al, 2019).

Developing oracy is considered beneficial for learners during school, and beyond. The ability to interact orally well and according to the context is regarded as a significant component of students' communication skills (Jackson, 2014). In this globalized world of the $21^{\text {st }}$ century, skills such as critical thinking, innovation, collaboration, problem-solving and global communication are essential and the ability to communicate orally in the English language is highly appreciated in all fields of life (Jackson, ibid). As English is the 'lingua franca' of the age, the skill to articulate ideas, negotiate and interact using the English language will lead to innumerable opportunities in education and the workplace (Goh, 2014). Even though literacy skills are still a requisite, the need for oracy skills, for international communication is, nowadays, imperative (Goh, ibid).

\subsection{Oracy and the Use of Video and You Tube}

The teacher is required to create an encouraging and motivating environment for the students to feel intrigued during language instruction. Nunan (1999) suggests that researchers should assure that all learners have fair and impartial opportunities to promote their interpersonal speaking and learning skills through small or large group discussions. From this perspective, the oracy class can benefit from the use of videos. Sherman (2003) defines videos as today's medium and states that people nowadays spend more time using audio-visual materials than printed ones. The combination of two different senses seeing and hearing -arouses interest and makes language presentation more comprehensible since it enables learners to study non-verbal elements such as posture and gesture (Slaouti\&Kanelopoulou, 2005). Canning-Wilson (2000) survey certifies that students like learning languages through videos and confirms that visual clues assist comprehension of the material.

In this technological age, however, the video is not limited to television. The emergence of the Internet gave a chance to instructors to apply online resources to traditional classes and facilitate language learning by making it meaningful and interesting. You Tube is regarded as one of the most efficient internet-based educational tools to stimulate students to learn owning to the videos it presents to them (Deng \&Yeun, 2010). You Tube offers various kinds of video content from video clips to films and even videos that are made by You Tube users some of which can be highly exploited in class. The teachers have the opportunity to select the videos that are suitable to pupils' needs and engage them in meaningful and motivating tasks so as to improve their oracy skills in a communicative framework. 
You Tube is an authentic source for class materials (Lee, 2010). In such an authentic context the students come to grips with real-life situations and are able to explore different cultures in a challenging and invigorating way (Cakir, 2006 cited in Argawati, 2014). Barrs (2012) states that this mode of instruction promotes cross-cultural development given that users from different cultures can upload videos on the platform, comment, share, edit and discuss. According to Alimemaj (2010) You Tube can boost autonomy because it triggers learners to watch clips or videos constantly even outside the classroom as application is available in their smart phones. Watkins (2011) also confirms that utilizing a You Tube video inside and outside the class can build authentic vocabulary knowledge, pronunciation, conversation and critical skills. Screening You Tube videos is a motivating and exciting way to learn faster in a stress-free environment without the limitation of the traditional classes where the educator is the dominant figure (Alhammai, 2013; Snelson\& Perkins, 2009). Many researchers worldwide have affirmed the positive impact of YouTube on language learning (Barrs, 2012), on speaking skills (Alhamami, 2013; Silviyanti, 2014), on the enhancement of fluency, vocabulary, pronunciation, grammar and content (Riswandi, 2016). You Tube is considered an innovation in learning which can retain pupils' attention, enable them to remember the input better and interact willingly and without restraint (Wagner, 2007). Students love the social media and You Tube, as such, can function as a learning tool that enhances and refines oracy skills in the 21 st century.

\section{THE RESEARCH METHOD}

\subsection{The Aim of the Research}

The purpose of this research study is to add insight into what extend the use of YouTube-video based lessons can refine the oracy skills through the application of differentiated instruction to a fifteen-year-old boy who is an English language learner of B2 level in order to enhance his listening and speaking skills.Based on the aim of this research, the specific research questions have been set:

1. Do YouTube-based video lessons enhance listening skills?

2. Do YouTube-based video lessons improve speaking skills?

3. Can the student improve his sentence structure and formation through YouTube-based video lessons?

\subsection{The Research Method}

For the needs of the particular research, a case study was conducted in order to answer to the aforementioned research questions regarding the development of oracy skills in an EFL context using YouTube videos. A case study is an in-depth and detailed examination of a specific situation, which will provide reference of the student's progress and permit a 'hypothesis' design and further analysis (Gerring,2011). The basic principle of a case study is that it attempts to elucidate a set of decisions, why they were taken, how they were applied, and with what outcomes (Yin, 1989 cited in Ebneyamini\& Moghadam, 2018). To triangulate this research so as to assure its validity and reliability qualitative research was applied in the form of semi-structured interviews. A qualitative approach can provide the researcher with the potential to depict multiple realities and encourage a subjective truth (Bogdan \& Biklen in Castellan, 2010). Interviews permit the researcher to gain knowledge of the interviewee's world and understand the meaning or the nature of the participant's day-to-day experiences (Palmer \&Bolderston, 2006). There are three different types, namely structured, semi-structured and unstructured interviews (Polit \& Beck, 2006). In the specific research semi-structured interviews (SSI) were conducted as a tool for data collection. The data that can be induced from SSI can provide rich, comparable and reliable qualitative data (Palmer \&Bolderston, ibid). The present study can also be characterized as an action research because the researcher is also an instructor who explores her personal teaching situation. Action research is an alternative, authentic and meaningful way to carry out research in the educational context in which the teachers/researchers participate in all the stages of the research (Hine, 2013).

\subsection{Pre- and Post- Tests}

Pre-test and post-test design is employed in experimental and quasi-experimental research in order to determine knowledge before and after the application of an approach, and it evaluates the degree of the development achieved (Dinitrov\&Rumrill, 2003). Pre-tests are administered before the beginning of the lesson, they are mainly diagnostic and learners are not expected to excel in them. They measure the preexisting knowledge, reveal the pupil's learning level and inform the instructor about the topics that require further elaboration (Kuehn, 2019). Post-tests are generally identical to the pre-tests which were assigned and they are administered directly after the completion of the intervention. In the specific research a KPG listening and speaking test of a B2 level was administered to the learner. 


\section{THE RESEARCH RESULTS}

\subsection{Pre- and Post- Tests Results}

The pre-test was conducted before the application of the intervention so as to determine the subject's competency level. Concerning the listening section, the learner's performance was very good in both parts $\mathrm{A}$ and B. More specifically, in part A 13 out of 15 items were correct $(86,6 \%)$ while in part B he had completed correctly 8 out of 10 items ( $80 \%$ ) and his total score was $83 \%$.Regarding the speaking part of the pre-test his performance was evaluated on assessment criteria which were grouped under two main categories, namely criteria for assessing task completion and language use (Karavas, 2009). Each criterion is accompanied by a 5-Point Likert Scale in order to minimize subjectivity in marking open-ended items and activities. In this framework, his overall speaking performance could be characterized as moderately satisfactory. In respect to activity 1 (Dialogue, in the form of an interview) the student had difficulty responding to the last question, there was hesitation and stuttering and he used his mother tongue in his attempt to ask for clarifications three times. Although in activity 2 (one-sided talk, based on visual clues) his performance was good as he developed ideas adequately for the social context, he made wrong use of the personal pronouns six times. As regards activity 3 (Mediation, based on a Greek source text) his performance was average as the student mostly translated rather than relayed Greek input. Even though he was comprehensible, he used only a few ideas from the Greek text.

The post-test was identical to the pre-test and its main aim was to reveal the differences regarding the learner's performance due to the integration of YouTube-video based lessons into the EFL instruction. The post-test findings present great interest as they show improvement in both listening and speaking parts which indicate the positive impact of YouTube lessons on fostering learner's oracy skills. Namely, in the listening part the student had scored $100 \%$ in part A and $90 \%$ in Part B which indicates an improvement of $13,4 \%$ in activity 1 and $10 \%$ in activity 2 in comparison to the pre-test results (Table 1). Overall, there was an advance of $11,7 \%$ in the student's performance regarding listening skills as table 2 illustrates.

Table 1: Scores in Activities 1 \& 2 in Pre- and Post-Listening Test

\begin{tabular}{|l|l|l|l|}
\hline & Pre-test & Post-test & Difference \\
\hline Activity 1 & $86,6 \%(13 / 15)$ & $100 \%(15 / 15)$ & $13,4 \%$ \\
\hline Activity 2 & $80 \%(8 / 10)$ & $90 \%(9 / 10)$ & $10 \%$ \\
\hline
\end{tabular}

Table 2: Total Scores in Pre- and Post-Listening Test

\begin{tabular}{|l|l|l|}
\hline Pre-test & Post-test & Difference \\
\hline $83,3 \%$ & $95 \%$ & $11,7 \%$ \\
\hline
\end{tabular}

Speaking was the part with the most evident development. In activity 1 and 2, the student responded to all the questions in a fully satisfactory manner. The speaker was comprehensible without any effort throughout the test. In activity 1 the student responded fully satisfactorily as he answered all the questions fluently and accurately. In activity 2 his performance was also adequate as his error was the wrong use of a verb tenses that occurred twice. Regarding activity 3 his performance was fairly satisfactory because he tried to relay information in the target language. Overall, in relation to the quality of language production there was an evident improvement in terms of pronunciation and intonation, lexical range, fluency, cohesion, coherence and communication strategies so as to avoid a breakdown in interaction this time. The findings show a distinction between the pre-test and the post-test score, thus, it could be concluded that there was an improvement in the use of YouTube-video based lessons in teaching oracy skills.

\subsection{Analysis of the Results of Semi-Structured Interviews}

The data derived from the semi-structured interviews were transcribed, analyzed and grouped into axes each of which referred to a particular thematic area. According to Creswell (2014) semi-structured interviews could be examined if the researcher categorized the questions through axial coding. The latter is a technique that relates data together so as to disclose categories and codes rooted with participants' opinions (Allen, 2017). The responses from the semi-structured interviews before the intervention were gathered into four axes each addressing a specific thematic framework whereas the answers of the semi-structured interviews 
after the intervention were grouped into two axes referring to a particular thematic area.

\subsubsection{The Semi-Structured Interviews Before The Intervention}

The first axis aimed at collecting demographic information, the participants were asked general questions (Laforest, 2009) to break the ice and to familiarize them with the process. Concerning the educational level of the interviewees, the mother stated that she had graduated from the Aristotle University of Thessaloniki from the School of Early Childhood Education whereas the student was attending the third class of Junior High School. The mother also stated that she is a proficient user of the English language as she holds a C2 level English Language certificate and the student had been learning the target language for five years at his State school while at the same time he was having English private lessons at home. Both participants affirmed that the mother helps the student in his English homework mainly by providing ideas in writing tasks or by explaining unfamiliar vocabulary to him. The father of the family works in the private sector, he has studied Technology in a Technological Institution and he does not speak English (Figure 1).

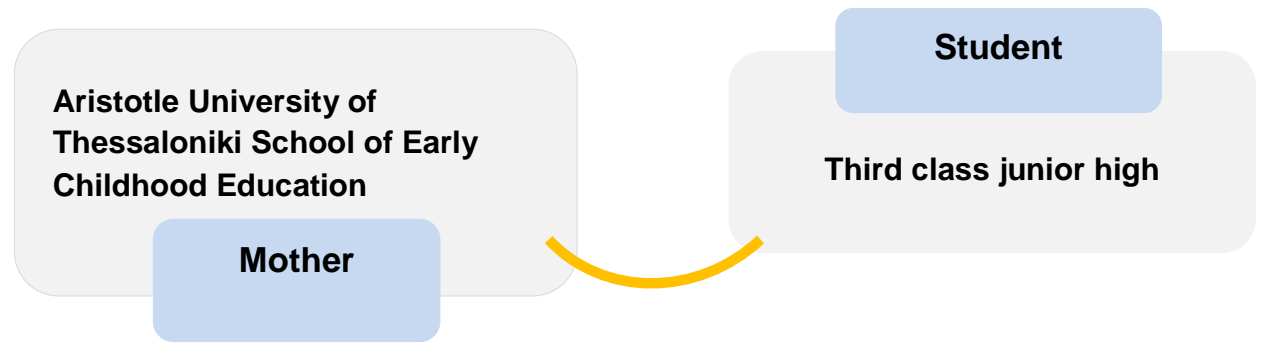

Figure 1: Qualifications of Participants

The second axis revolved around general questions about the student's education and his attitude towards the English lesson. According to the answers provided, the latter likes school in general and as regards the English lesson he has a positive attitude towards it, he finds the vocabulary and grammar easy to learn while he faces difficulties in speaking (Ur, 1996) and writing skills. The mother claimed that even though the student expresses his difficulties regarding the English language to her, he does not seem to be concerned about the issue. The student, on the other hand, mentioned that he tried to work harder on the problematic areas by learning fixed statements and sentences by heart and by devoting more time on speaking, and writing tasks (Figure 2).

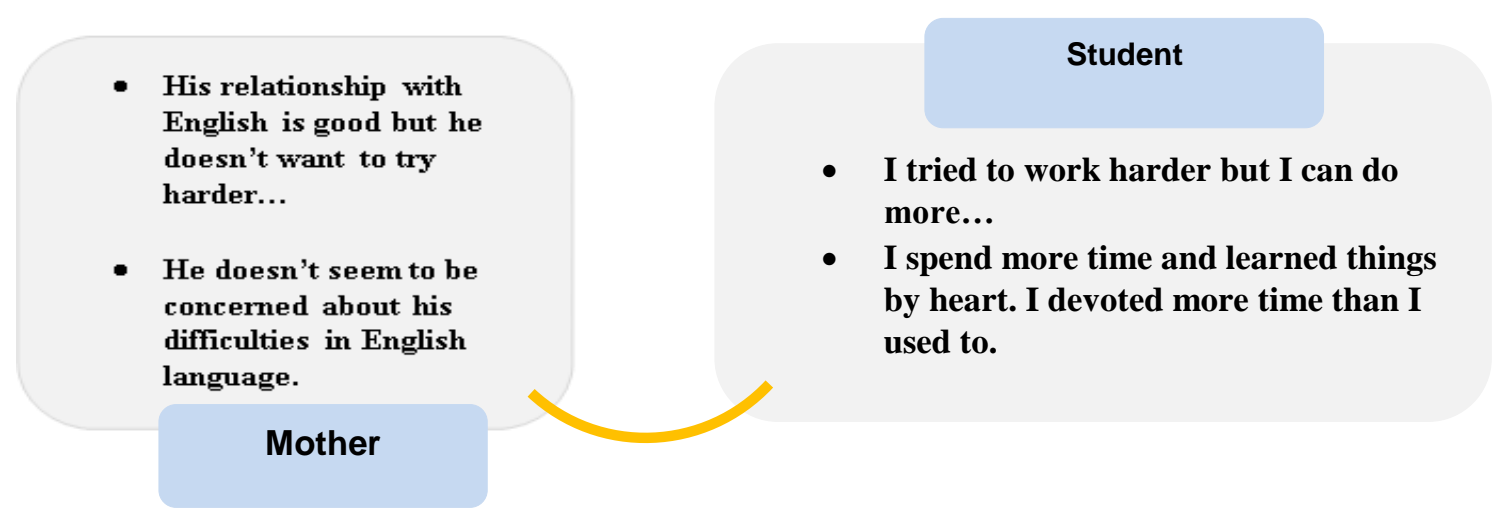

Figure 2: Exploring Student's Attitudes towards the English Lesson

As far as the third axis was concerned, the questions explored the English lesson focusing mainly on oracy skills (Figure 3). In particular, the mother expected English language teachers to help the student learn how to communicate efficiently in the target language. According to her a language certificate is of little value nowadays unless the student is able to interact in English (Goh, 2014). She contended that teachers should insist on teaching oracy skills and to speak only in English during the tasks. As regards the listening skills he claimed that his weaknesses in the specific modality could be dealt by watching videos, films and by doing more listening tasks (Chang \& Chang, 2014). Concerning his speaking skills, he admitted that he cannot speak fluently with a native speaker and that it is necessary to improve his speaking skills (Ur, 1996). The participants' views converge with regard to oracy skills since they consider that further practice is required (Alexander, 2012). 


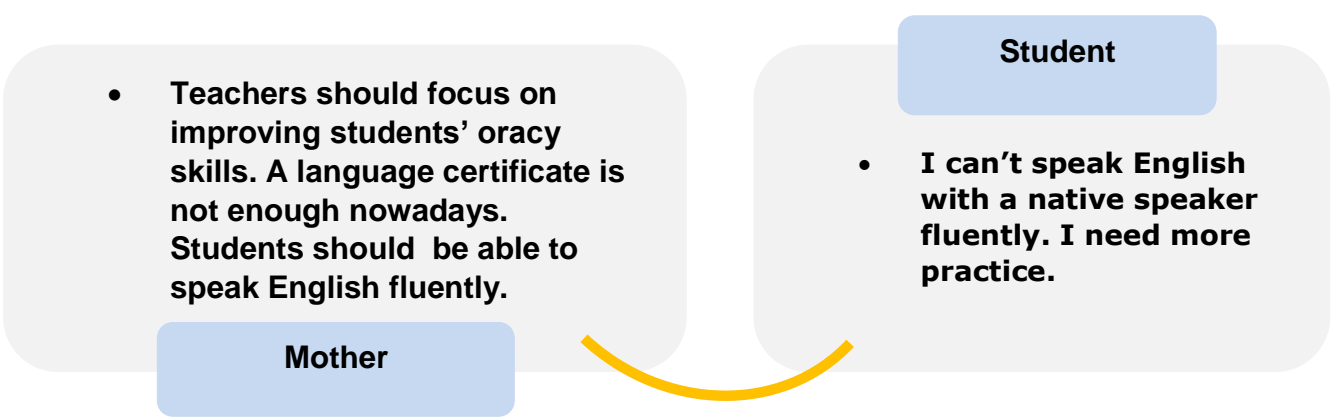

Figure 3: English Language and Oracy Skills

The fourth axis focused on technology and education. The student stated that his relationship with technology is very good as he uses the Internet for approximately three hours a day. He also added that he likes watching videos on YouTube and he considered the integration of YouTube videos in the English lessons an interesting option because the platform can spark variety (Albahlal, 2019). The above are in line with the mother's perceptions who apart from advocating the assistance of YouTube videos in contemporary EFL teaching (Jalaluddin, 2016) because students are keen on learning with the use of technology (CanningWilson, 2000), she also contended that instruction should focus on students' interests and predilections (Figure 4).

\section{Student}

- The use of Youtube videos would help in English lessons.

- Instruction should focus on students' interest.

Mother
- Through YouTube videos I would learn some expressions, the pronunciation of some words and new vocabulary.

\section{Figure 4: Technology and Education}

\subsubsection{The Semi-Structured Interviews After The Intervention}

The first axis investigated the changes that were observed in the student with regard to oracy skills. Namely, the mother replied that the student liked YouTube-video based lessons because the whole procedure was a challenge for him. She also stressed that his listening skills were improved because the combination of image and sound that videos offer made the student pay more attention during the lesson and helped him understand the material (Oddone, 2011). In addition, according to the mother his speaking skills were also enhanced mainly in terms of fluency (Riswandi, 2016). The student found YouTube-video based lessons more enjoyable "...instead of doing the same things over and over again, we do something different through the use of YouTube videos. I learnt more things and in a more pleasant manner". He stated that his oracy skills improved because after the intervention as he felt more confident than before to interact with a native speaker. He also stated that his pronunciation was ameliorated (Wagner, 2007) after the ten lessons. Finally, both participants would like YouTube integration into English lessons, ideally once a week, so as to practice and improve oracy skills (Figure 5).

- Sound and image combination help understanding and made him more attentive.

- He has got more fluency now.

\section{Student}

- I've learned how to listen and understand the aural text better.

- At first, I didn't know what to say. Now I know. l've got ideas.

Mother

Figure 5: Changes Observed in Terms of Oracy Skills 
On the second axis participants were asked questions concerning the YouTube video's impact in EFL instruction (Figure 6). According to the student YouTube videos can function as a source of ideas and arguments in various contemporary issues and can also broaden his intellectual horizons, "...before the lessons I didn't have so many ideas. Now I have lots of ideas". The above are in line with the mother's perspective on the issue. Furthermore, as reported by the mother YouTube videos should be integrated in EFL since she regards them as a "convenient and smart" solution; the student, on the other hand, believes that it is hard to incorporate YouTube videos in the school curriculum because the majority of Greek schools lack the necessary equipment for their implementation in the English lesson. Finally, he claimed that he is not willing to watch YouTube videos on his own initiative in order to boost his oracy skills, yet, his mother stated that he will do it unintentionally because he enjoys watching videos and using technology in general (Alimemaj, 2010).

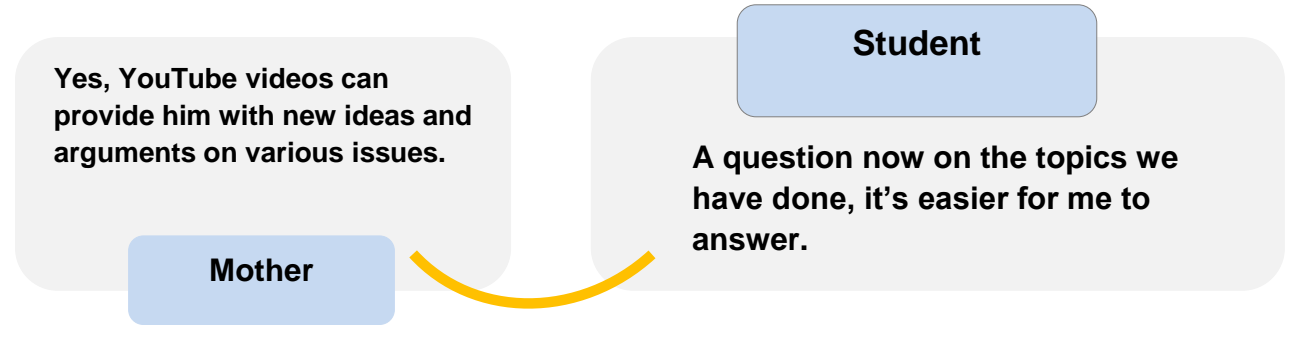

Figure 6: YouTube Impact on EFL

\section{DISCUSSION}

\subsection{Revisiting the Research Questions}

Based on the findings presented in chapter 4, YouTube videos appear to develop and refine oracy skills while they can bolster sentence structure and formation with the aid of differentiated instruction. The results of the pre- and post-test, the ten lessons of the action research and the semi-structured interviews provided the answers to the three questions of this research study.

\section{Do YouTube-video based lessons enhance listening skills?}

The first research question revolved around the efficiency of YouTube videos for the development of listening skills. The ten lessons of the action research, the findings of the semi-structured interviews and the difference in the listening pre- and post-test scores showed an improvement on the particular modality. The ten lessons refined his aural skills as the student gained confidence in tackling authentic off-air listening input. The aforementioned are in line with the findings of the interviews in which the participants also stated that YouTube videos affected the student's listening ability because the picture was highly helpful with regard to comprehension (Godwin-Jones, 2012). Finally, the pre- and post-listening tests verify this result as the learner performed better in the post-test.).

\section{Do YouTube-based video lessons improve speaking skills?}

The second question focused on the effectiveness of YouTube on the speaking modality. According to the data collected fromthe ten lessons, the semi- structured interviews and the comparison of the pre- and postspeaking test results, it could be concluded that the application of YouTube can significantly refine the speaking skills. Based on the action research results his self-confidence concerning speaking tasks was gradually boosted, because he started retrieving and applying the video's information in order to express himself. Moreover, the YouTube-based video lessons created a relaxed atmosphere that lowered his anxiety in relation to his speaking performance which in turn aided in the enhancement of his oraskillsl.

\section{Can the student improve the sentence structure and formation through YouTube-based video lessons?}

The third research question examined whether the student can enhance sentence structure and formation through YouTube videos. In particular, according to the ten lessons of the action research the student had some grammatical errors which were diminishing during the intervention lessons as he felt relaxed and he gradually became aware of them and corrected himself. The semi-structured interviews confirmed this finding, because the student claimed that he felt more confident after the intervention lessons and he stated that he could interact with a native speaker better than before. The pre- and post-test results, also, validate these findings. His performance concerning sentence structure and formation was obviously improved as during the post-test the student responded fully satisfactorily regarding grammatical structures and sentence 
patterns. Sporadic errors might have occurred but there was, in general, a high degree of grammatical accuracy.

\subsection{Limitations and Proposals for Further Research}

The existence of some limitations cannot be dismissed. The current research limits itself to one student, thus the results cannot be generalized (Anisimora\& Thomson, 2012). Furthermore, another limitation is the fact that the study lasted for only one month, which may not be adequate to refine oracy skills. A longitudinal research may be more informative regarding the effects of YouTube-video based lessons on speaking and listening skills. Yet, the successful completion of the lesson plans can function as an outset for further research to be conducted in the field of YouTube integration in EFL focusing not only on oracy skills but also on literacy, vocabulary and grammar skills. A final suggestion would be to conduct further research that will focus on teachers' perceptions as well as students' perspectives concerning the application of YouTube for language development.

\section{CONCLUSION}

This research focused on one English language student of a B2 level and his mother who participated in the semi-structured interviews. In order to achieve the aims which were set a combination of methods were applied to triangulate the research. The qualitative data collected, proved that YouTube-video based lessons were beneficial to the student as the latter advanced his speaking and listening skills and exhibited greater motivation towards the English lessons. Overall, the application of YouTube videos improved the student's oracy skills. Therefore, YouTube videos constitute an effective and valid source to teach and refine oracy skills in a meaningful and enjoyable manner.

\section{REFERENCE LIST}

Albahlal, F. S. (2019). The impact of YouTube on Improving Secondary School Students' Speaking Skills: English Language Teachers' Perspectives. Journal of Applied Linguistics and Language Research, $6^{\text {th }}$, $1-17$.

Alexander, R. J. (2012) Improving Oracy and Classroom Talk in English Schools: Achievements and Challenges. Extended and referenced version of a presentation given at a Department for Educational seminar on Oracy, the National Curriculum and Educational Standards. London, 20 February 2012.

Alimemaj, Z. (2010). YouTube, language learning and teaching techniques. Anglo Higher, vol. 2

Allen, M. (2017). The SAGE encyclopedia of communication research methods. Los Angeles, CA: SAGE Publications, Inc.

Anisimova, T., \& Thomson, B. (2021). Enhancing multi-method research methodologies for more informed decision-making.

Argawati, N.O.(2014). Improving students' speaking skills using group discussion (Experimental Sudy on the first grede students of senior high school). ELTIN Journal, vol. 2.

Barrs, K.,(2012). Fostering computer-mediated L2 interaction beyond the classroom. Language learning \& Technology, vol. 13.

Baxter, P., \& Jack, S. (2015). Qualitative Case Study Methodology: Study Design and Implementation for Novice Researchers. The Qualitative Report. doi: 10.46743/2160-3715/2008.1573.

Byrnes, H. (2007). Developing National Language Education Policies: Reflections on the CEFR. The Modern Language Journal, vol.91.

Canning-Wilson,C.,2000. Practical Aspects of Using Video in the Foreign Language Classroom, The Internet TESL Journal, vol. VI.

Castellan C. M. (2010). 'Quantitative and qualitative research: A view for clarity'. International Journal of Education, vol.2.

Chang,C.,\&Chang,C.K.(2014). Developing Students'ListeningMetacongitive Strategies Using Online Videotext Self-Dictation-Generation Learning Activity. The EUROCALL Review. Vol.22 . 
Council of Europe (2001). Common European framework of reference for languages: learning, teaching, assessment. Cambridge: Cambridge University Press

Council of Europe (2021). Common European Framework of Reference for Languages: Learning, Teaching, Assessment-Companion Volume.

Creswell, J. W. (2014). Research Design: Qualitative, Quantitative, and Mixed Methods Approaches (4th ed.). Thousand Oaks, Calif.: Sage Publications.

Deng, L. \& Yuen, A.(2010). Towards a framework for educational affordances of blogs. Computers \&Education, vol. 56.

Dimitrov. D. M. \&Rumrill, Jr, P. D. (2003). 'Pretest- posttest designs and measurement of change'. In IOS Press, vol. 20.

Ebneyamini, S., \& Sadeghi Moghadam, M. R. (2018). Toward Developing a Framework for Conducting Case Study Research. International Journal of Qualitative Methods

Gerring, J.(2011). The Case Study: What it is and What it Does. In The Oxford Handbook of Political Science.: Oxford University Press.

Goh, C.(2014). Reconceptualising second language oracy instruction: Metacognotive engagement and direct teaching in listening and speaking. The Asian Journal of English Language and Pedagogy.

Hine, G.S.C. (2013). The importance of action research in teacher education programs. Issues in Educational Research: Special Issues, vol.23.

Hughes, R. (2002). Teaching and Researching Speaking. New York: Pearson Education.

Jackson, D. (2014). 'Business graduate performance in oral communication skills and strategies for improvement.' International Journal of Management in Education, vol.12.

Jalaluddin, M. (2016). Using YouTube to Enhance Speaking Skills in ESL Classroom. English for Specific Purposes World, vol.17.

Jones, A.(2004). A Review of the Research Literature on Barriers to the Uptake of ICT by Teachers. BectalCT Research (British Educational Communications and Technology Agency).

Kaldahl, A.G., Bachinger,A., Rijlaarsdam,G.(2019). Oracy matters. Introduction to the special issue on oracy.Editorial to a special issue on Assessing Oracy, edited by Anne-Grete Kaldahl, Antonia Bachinger, and Gert Rijlaarsdam. L1-Educational Studies in Language and Literature, vol.19.

Karavas, K. (2009). THE KPG SPEAKING TEST IN ENGLISH: A HANDBOOK. RCeL Publications, University of Athens.

Kuehn, P.R. (2019). Function and Importance of Pre and Post-Tests.

Laforest, J.(2009). Guide to Organizing Semi-Structured Interviews with key Informant, Charting a Course to Safe Living. Vol.1. Quebec

Lee, L. (2010). Fostering reflective speaking and interactive exchange through blogging in an advanced language course. ReCALL, vol. 22.

Little, D. (2006). The Common European Framework of Reference for Languages: Content, purpose,

origin, reception and impact. Language Teaching, vol. 3

Nunan,D.,(1999). Second Language Teaching \& Learning. Boston: Newbury House Teacher Development.

Oddone, C. (2011). Using Videos from YouTube and Websites in the CLIL Classroom. Studies About Languages, O(18). doi: 10.5755/j01.sal.0.18.417

Palmer, C., \&Bolderston, A. (2006). A Brief Introduction to Qualitative Research. Canadian Journal Of Medical Radiation Technology, vol. 37.

Polit, D. \& Beck, C. (2006). Essentials of Nursing Research. Methods, Appraisal, and Utilization. Sixth edition. Lippincott Williams and Wilkins, Philadelphia PA.

Riswandi, D. (2016). Use of YouTube-Based Videos to Improve Students' Speaking Skills. Paper presented at The $2^{\text {nd }}$ International Conference on Training and Education, SebelasMaret University. 
Sherman,J.(2003). Using Authentic Video in the Language Classroom. Cambridge: Cambridge University Press.

Silviyanti,T. (2014). Looking into EFL Students' Perceptions in Listening by Using English Movie Video on YouTube. Studies in English Language and Education, vol.1

Slaouti, D., Kanellopoulou, M.(2005). Educational Technology in English Language Teaching.(Volume 1). Patras: Hellenic Open University.

Snelson, C., \& Perkins, R.A. (2009). From silent on film to YouTube: Tracing the historical roots of motionpicture technology in Education. Journal of Visuals Literacy. vol.28

Tomasello, M. (2010). Origins of human communication. MIT Press. Google Scholar

Ur, P. (1996). A Course in Language Teaching: Practice and Theory. Cambridge: Cambridge University Press.

Vygotsky, L. S. (1962). Thought and Language.Cambridge, MA: MIT Press.

Wagner,E. (2007). Are they watching? Test-taker viewing behavior during an L2 video listening test. Language Learning and Technoloy,vol.1K

Watkins,J.,\& Wilkins, M. (2011). Using YouTube in the EFL Classroom. Language Education in Asia,vol.2 (

Wilkinson, A. (1965). The Concept of Oracy . Educational Review, vol. 17.

Wilkinson, A. (1965). Spoken English. Birmingham: University of Birmingham Press. 